\title{
Tumour necrosis factor-a(-308) polymorphism and the risk of gastric cancer: A meta- analysis and trial sequential analysis
}

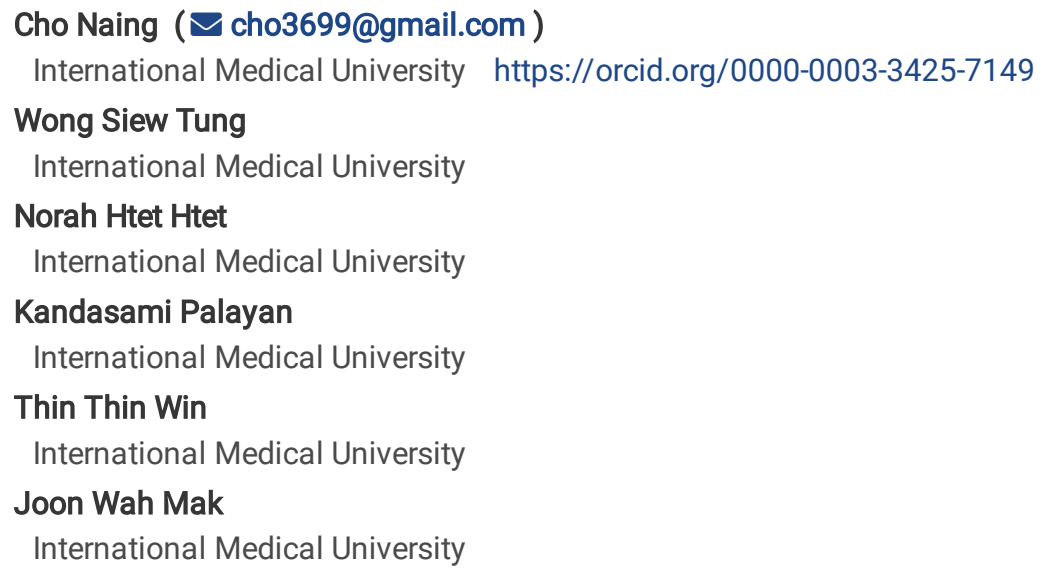

Research article

Keywords: gastric cancer, risk factor, Tumour necrosis factor, meta- analysis.

Posted Date: September 25th, 2019

DOI: https://doi.org/10.21203/rs.2.15284/v1

License: (c) (i) This work is licensed under a Creative Commons Attribution 4.0 International License. Read Full License 


\section{Abstract}

Background: Numerous studies have reported that polymorphisms in the tumour necrosis factor-alpha (TNF-a-308) gene are implicated in susceptibility to gastric cancer. However, individual genetic association studies that assessed the relationship between TNF-a- 308 and the risk of gastric cancer showed inconclusive results. The objective of this study was to synthesis evidence on the association between polymorphisms in the TNF-a-308 and gastric cancer risk. Methods: This is a meta-analysis of genetic association studies. We searched relevant case-control studies, assessing TNF- 308 polymorphisms and gastric cancer in health-related electronic databases. The methodological quality of included studies was assessed by the Newcastle-Ottawa quality assessment scale. The strength of association was calculated as odds ratios (ORs) with its $95 \%$ confidence intervals (Cls). Pooled ORs and $95 \% \mathrm{Cls}$ were estimated using random-effect model or fixed effect model, based on between-study heterogeneity. We analysed the strength of association under dominant, recessive, additive and allele models. Multiple subgroup analyses including ethnic groups, HWE status, study quality were done for robustness of the estimates. Publication bias was detected by inspection of funnel plot asymmetry. Results: A total of 33 studies, comprising 7695 patients and 12327 controls were identified. Based on the studies that met HWE, significant association was found between this polymorphisms and gastric cancer risk under dominant model (OR 1.2, 95\% Cl 1.1-1.3, I $2: 37 \%)$, recessive model OR $1.27,95 \% \mathrm{Cl} 1.0-1.62, \mathrm{I} 2: 0 \%$ ) and additive model (OR 1.31, 95\% Cl 1.08-1.32, I $2: 0 \%)$. The TSA plot indicated the analyses was with the required information size. There was no publication bias. In the subgroup analysis by ethnicity, the ethnic groups and the quality of studies had impact on the estimates.

Conclusions: The findings suggest that TNF-a-308 gene polymorphism plays an important role as host genetic factor predisposing to gastric carcinogenesis, and it would be useful for a screening marker.

\section{Background}

Gastric cancer (GC) is globally the fifth most common cancer with the highest prevalence in both sexes in Asia (74.5\%) and the third leading cause of cancer death In 2018 alone, the estimated number of deaths attributed to GC was 782,685. On gender-specific, GC is the fourth most common types of cancer occurred in men and the seventh most common cancer in women [1]. As such, a greater understanding of the risk factors that play a role in the early and late stages of gastric carcinogenesis is important to strengthen and improve the preventive and therapeutic interventions [2].

Epidemiologic studies showed that GC is a multifactorial in aetiology [3, 4], in which dietary factors and Helicobacter pylori infection may contributed to the development of GC [3]. Of note is that a high prevalence of these risk factors do not always correspond to a high incidence of GC, suggesting that other susceptible factors such as genetic variations and environmental differences may play a role in the gastric carcinogenesis [5]. For instance, H. pylori infection is observed in more than half of the world's population, however there is only $1-2 \%$ of the infected population will develop GC in their lifetime [6].

Gastric neoplasms are composed not only with cancer cells but also other "non-cancer" compartments (including immune cells), which are the major players in GC disease progression and aggressiveness [7]. Tumour necrotic factor (TNF) is a pro-inflammatory cytokine, which is produced mainly by the immune cells such as macrophages, dendritic cells, lymphocytes and mast cells [8]. The tumour microenvironment, which is mainly composed of inflammatory cells, is a crucial player in the neoplastic process, fostering proliferation, survival and migration [9]. Thus, TNF-a may through inflammation, act as a tumour promoter. Individual studies reported the significant relationship between TNF- a -308 (rs 1800629) and the risk of GC [10, 11]. However, other studies reported differently $[12,13,14]$. On the whole, the objective of this study was to summarize the evidence of association between TNF-a-308 and the risk of GC.

\section{Methods}

\section{Study search}

The search of relevant studies was performed in the health-related databases of PubMed, Ovid Medline, google scholar and web of science, using the terms ("gastric cancer" OR "gastric carcinoma" OR "stomach cancer" OR gastric adenocarcinoma AND "tumour necrosis factor- alpha-308" OR "rs1800629" OR "TNF-a-308 G>A" OR "TNF-a-307 G>A"). The search strategy in PubMed database is provided (Additional File 1: Table S1).

The search was limited to the publications in English until June 2019. Moreover, we searched manually the references of included studies and relevant systematic reviews for any additional studies.

\section{Inclusion criteria}


Human studies that assessed GC, irrespective of location or histological type were included, if they (i) assessed TNF- $a-308$ G>A (rs 1800629) or TNF-a-307 G>A; (ii) were case-control design (retrospective or nested case-control) with an outcome of GC risk; (iii) provided the genotype frequency in cases and controls, (iv) mentioned sufficient data to compute odds ratio (OR) and its $95 \%$ confidence interval (CI) as the outcome measure. GC is as defined in the primary studies.

Studies which did not meet the inclusion criteria were excluded. Studies done on family or sibling-pairs were also excluded.

\section{Data extraction}

One investigator screened the titles and abstracts and selected the relevant full-text articles, following the inclusion criteria. Two investigators extracted the data from each study independently, by using a piloted data extraction form. Information collected included: first author, publication year, country, study setting, the number of cases/controls, ethnicity (Asian or Caucasians), method of genotyping and genotype/allele frequencies in cases/controls. If an allele frequency was zero in both case and control, we added 1 to that allele, following the Laplace approximation [15]. Any discrepancy between the two investigators were resolved by consensus.

\section{Assessment of the methodology quality}

The two investigators independently evaluated the methodological quality of studies, using the Newcastle-Ottawa Scale (NOS) [16]. The assessment is based on the three factors such as 'selection of the study groups' (4 points), 'comparability of the groups' (2 points) and 'ascertainment of the exposure' (3 points). The total score for each study spanned from 0 (the worst) to 9 (the best). We categorised study quality as good $(\geq 7)$, moderate $(\geq 5)$ and poor $(\leq 4)$, according to scores achieved. Any discrepancy between the two investigators was resolved by consensus.

\section{Statistical analysis}

We assessed an evidence of HWE in the control populations in the included studies using the goodness-of-fit test and $p>0.05$ was considered to indicate consistency with HWE [17]. As described elsewhere [18], the strength of the association between TNF-a-308 G>A and the risk of GC in each study was estimated using OR and its $95 \% \mathrm{Cl}$. Between- study heterogeneity was determined with the $R$ test. The $R$ test values indicate the percentage of total variation across studies attributed to the heterogeneity rather than chance. $P$ values $>50 \%$ is regarded as a substantial heterogeneity [19]. For pooling of the estimates, the summary ORs and its $95 \%$ Cls were calculated with the random-effect model (The Der Simonian and Laird method) in the presence of statistical heterogeneity of the studies. Otherwise, we used the fixed-effect model. We calculated the summary ORs and its $95 \% \mathrm{Cls}$ in four genetic models: the allelic contrast model (A vs $\mathrm{G}$ ), the dominant model ( $A A+G A$ vs $G G)$, the recessive model (AA vs $G A+G G)$, and the additive model (AA vs $G G)$. In order to investigate the source of heterogeneity, several subgroup analyses were conducted under the dominant model such as the ethnicity, study quality. Moreover, a subset analysis was done on the gene frequency distribution by location or histological type of GC. As a sensitivity analysis, we reassessed the relationship between TNF- a 308 and the risk of GC in all 4 genetic models, after removal of studies that deviated from HWE The publication bias was assessed by visual inspection of funnel plots under dominant model [20, 21].

\section{Trial sequential analysis (TSA)}

To estimate the required information size, we performed trial sequential analysis (TSA) [22]. It is classified as 'firm evidence of effect' or 'potentially spurious evidence of effect', which depends on whether the cumulative Z-curve cross the monitoring boundaries or not [23]. Meta-analysis was done with RevMan 5.3 (The Cochrane collaboration, Copenhagen) and metan command in Stata 14 (Stata Corp, Txt). TSA plot was done with TSA software (Copenhagen Trial Unit, Centre for Clinical Intervention Research, Copenhagen).

\section{Results}

\section{Study search results}

Figure 1 illustrates a four-phase study selection process. The initial search yielded a total of 1322 records. After removing the duplicates and screening of abstracts, 43 full-text articles that were potentially eligible were retrieved. We included a final of 33 studies (with 
7695 cases and 12327 controls) in this review $[2,5,10-14,24-49]$. Summary of the 10 excluded studies were provided (Additional File 2: Table S2).

\section{Study characteristics}

Table 1 shows the characteristics of the studies identified. Of 33 studies included, slightly more than half (54.5\%, 18/33) were done in the Asian region. The most frequent 5 studies were conducted in China, South Korea or Brazil. Figure 2 shows geographical distribution of the studies included. The years of publication were from 2001 to 2017 . The participants were adults with male predominance in all 33 studies. In total, $82 \%$ of the studies were consistency with HWE in genotype distribution of the controls.

Regarding the methodology, the majority (78.8\%) were categorized as high (14 studies) or moderate quality (12 studies) and the remaining 7 studies were of low quality. Of total 33 studies, 8 studies (24\%) were gastric adenocarcinoma stage. By anatomical locations or histological types of GC, only 5 studies (7 datasets) consistently provided data that could make pooling of analysis (2,10,13,35,45). Twelve studies (36.4\%) used TaqMan method for genotyping. In total, 24 studies (72.7\%) had provided information that GC cases were infected with $H$. pylori infection, albeit with variation in distribution. For instance, all cases (100\%) were infected with $H$. pylori in one study [33], while this was only $46 \%$ in another study [2] (Table 1). The remaining 9 studies did not measure $H$. pylori status of the participants or not reported the status explicitly.

\section{Quantitative estimates}

The genotype frequencies in individual studies are presented in Table 2. Overall, there were significant associations between TNF$\mathrm{a}-308 \mathrm{G}>\mathrm{A}$ and the $\mathrm{GC}$ risk under the allelic model (OR,1.22;95\% Cl,1.04-1.44, $2: 78 \%)$ and the dominant model (OR,1.25;95\%Cl:1.08-1.45, $R: 69 \%)$, but not under the additive model (OR,1.22;95\% Cl:0.99-1.52, $P: 0 \%$ ) or the recessive model (OR,1.8, 95\% Cl; 0.96-1.46, $R: 2 \%)$. On stratification, only the Caucasian population showed susceptible to the GC risk under the allelic model (OR,1.27;95\% Cl,1.02-1.59, $P: 80 \%)$ and the dominant model (OR:1.25, 95\% Cl; 1.1-1.43, P:39\%) (Figure $3 \mathrm{~A}, \mathrm{~B}, \mathrm{C}, \mathrm{D})$ ).

\section{Subgroup analyses}

TNF-a-308 G>A was with an increased risk of GC only with the high quality studies (Additional File 3: Figure S1). Based on a subset of 5 studies (with 7 datasets), there were no significant differences in distribution of gene frequency between the sites of GC (cardia vs Noncardia) (OR: 0.84, 95\% Cl: 0.58-1.23) or histological types (diffuse vs intestinal) (OR: 0.71, 95\%Cl: 0.49-1.03) (Additional File 4: Figure S2)

By stratification on $H$. pylori infection status, overall TNF-a-308 G>A had a 25\% increased risk of GC in those infected cases compared to non-infected cases (OR,1.25, 95\% Cl; 1.08-1.45); however, this association was with a substantial heterogeneity ( $P$ :69\%) (Additional File 5 : Figure S3).

The pooled analysis on the 27 studies that were consistent with HWE also showed that TNF-a-308 G>A polymorphism was significantly associated with an increased risk of GC under the dominant model in overall analysis (OR,1.2;95\%Cl:1.1-1.3, $2: 37 \%)$, regardless of ethnic groups. Moreover, this association showed a decreased statistical heterogeneity (i.e. $P$ values from $69 \%$ to $37 \%$ ). In the recessive model, there was a significant association in overall analysis (OR,1.27;95\% $\mathrm{Cl}: 1.0-1.62)$ in the absence of statistical heterogeneity $\left({ }^{2}: 0 \%\right)$, but not in any particular ethnic group. This pattern was not found under the allelic model, which changed from a significant association into no significant association (OR,1.17,95\% Cl,0.98-1.39, $P: 75 \%$ ). Under the additive model, there was a significant association in overall analysis $\left(\mathrm{OR}, 1.31 ; 95 \% \mathrm{Cl}: 1.08-1.32,2: 0^{\%}\right)$, but not in any particular ethnic group) (Table 3). A funnel plot showed no evidence of publication bias (Additional File 6: Figure S4).

\section{TSA plot}

We performed TSA of the dominant model with the use of an overall type I error of $5 \%$ and type II error of $20 \%$. The included total participants in this meta-analysis reached the required information size (for an expected RRR 26\%). Briefly, a TSA monitoring boundary 
crossed with $Z$ curve, which confirms the presence of robust evidence (Figure 4). In such case further studies are not needed to provide sufficient information.

\section{Discussion}

The current study provides evidence on the relationship between TNF-a-308 G>A and the risk of GC, comprising 7695 cases and 12327 controls from 33 studies. The major observations are as follows;

1. Based on 27 studies that met HWE, TNF-a-308 G>A SNP was significantly associated with the GC risk under the dominant, recessive and addictive models.

2. On stratification, HWE status of the controls, the ethnicity or study quality had an impact on the effect estimates.

3. The TSA plot revealed that the required information size for evidence of effect was sufficient. Any future studies in this field will less likely to change the direction of estimates.

Our findings were comparable with earlier reviews, in which the significant association was limited to the Caucasians [50, 51] in the dominate models $[11,51]$. The association was statistically significant only for the Caucasians, indicating a dominance of racial specific factors. This difference may be explained partly due to variations in the frequency of the A allele between the different ethnic groups that could contribute to the diverse results. Moreover, it might also be related to difference in environmental factors such as smoking and diet between these two major ethnic groups. This was indirectly supported by an individual study in Poland, in which $72 \%$ of the GC cases were smokers (ex-smokers or current smokers) [39]. Due to paucity of data, we were not able to perform subgroup analysis with the smoking status of participants in the studies identified. The effects of inflammatory polymorphisms might have been masked by smoking [35]. Moreover, there was no significant differences of the gene frequencies between the anatomical sites or the histological types of GC. A silico analysis of TNF expression, using the bioinformatics web GEPLA had reported that the expression of TNF in GC tissue was higher than in normal stomach $(p<0.01)$ [52]. A published meta-analyses [50] focused on this polymorphism in the risk of GC reported that $H$. pylori infected cases had higher risk of developing GC. This was also observed in the present review.

The current findings suggest that $H$. pylori infection had contributed to a $30 \%$ increased risk of association between TNF-a-308 $\mathrm{G}>\mathrm{A}$ and the GC. This could be explained in the light of immune-biological plausibility. H. pylori infection activates the synthesis of cytokines in the lining of the stomach. The most commonly studied inflammatory-related genes in gastric diseases include TNF-a, among others. During the early stage of $H$. pylori colonization, the expression of TNF-a is up-regulated and this activates the transcription of various proinflammatory cytokines and chemokines, leading to the amplification of inflammatory cascade against the infection [53]. TNF-a has been shown to inhibit the gastric acid secretion which is important in inducing cell apoptosis and promoting epithelial cell damage [54]. The cellular immune response to $H$. pylori infection is a main factor which contribute to the damage in gastric mucosa. Studies reported that the hypochlorhydric milieu plays a role in promoting the growth of non- $H$. pylori bacteria, which may cause the damage to mucosal wall and/or the production of carcinogenic N-nitroso compounds [55]. Moreover, $\mathrm{H}$. pylori infection activates the cytokines production in the lining of the stomach including inflammatory-related genes such as TNF- a in the present analysis.

Our findings of overall or sensitivity analyses had some similarities to earlier reviews, in which the significant associations were also found with the dominant, allelic, additive models and recessive models, despite variations in number of studies [11, 50, 51]. Although there are more recent studies in this analysis, the results, in general, retained the evidence of association. Moreover, we introduced TSA for confirmation of the estimates to assess a required information size. TSA plots indicated that there was sufficient information to provide conclusive results.

\section{Public health Implications}

The difference in association between the ethnic groups observed in the current analysis has implications. Studies had reported that the regulation of tumor immunity factors at the genetic and gene expression level may be different in the Asian and non-Asian GC populations, and this can affect the region-specific effects on therapy outcome and prognosis [56].

\section{Limitations}


We acknowledge the study limitations. Only $36 \%$ of the studies in this review used TaqMan SNP genotyping assays, which is the preferred technology due to its high throughput and is highly accurate [57] compared to other methods. Hence, accuracy of genotype frequency is of concern as some studies included in this analysis were small studies with small sample sizes. Hence, there might likely have type II statistical error. However, meta-analysis is a retrospective pooling of published studies, and type II errors are less likely than in individual studies.

There might be other confounding factors that were not included in our subgroup analyses. For example, infections with carcinogenic potentials (e.g. EBV) or smoking and alcohol drinking of the participants were not addressed due to limited data. This bias was likely to be pronounced as the calculations used unadjusted assessment of ORs. Moreover, it is likely to miss relevant studies that are available in nonEnglish or non-indexed databases. Furthermore, there might be interactions of TNF-a and other genes such as interleukins (gen-gen interaction/synergism) or other potential confounding factors such as nutritional status and life style of the patients that might have significant roles in the GC risk. Due to limited number of studies, we could not perform pooled analysis with these potential confounding factors. Hence, findings in this meta-analysis should be interpreted with cautions in relation to these factors.

Nevertheless, there are strengths in our present meta-analysis study. More than half of the included studies were carried out in the Asia region, in which the GC was more prevalent. This implied that there was geographical representativeness. Moreover, the majority of GC patients in the primary studies identified for the present analysis were males. This also implied a gender representativeness in terms of higher prevalence of GC among males globally. The vast majority of included studies had evidence of HWE. Numerous studies had highlighted the issue of deviations from HWE in genetic association studies such as genotyping error, population admixture/substructure, among others [58-60]. Furthermore, for robustness of the findings, we have attempted several subgroup analyses. Additionally, there are some strengths in this meta-analysis compared with published reviews in this field [11,50,51,58-60]. To be comprehensive, we have attempted the TSA technique, which is useful to adjust random-error risk. An add-on TSA approach to this field will highlight to researchers about the optimal sample size to make judgement of the effect estimates. This will help the researchers and policy makers to consider on the need of future similar studies. This will further help to save the resources for more important future studies, rather than repeating a study that has been already confirmed.

\section{Conclusions}

The current findings suggest that $T N F-a-308$ gene polymorphism plays an important role as host genetic factor predisposing to gastric carcinogenesis, and it would be useful for a screening marker. As the relationship of GC risk is ethnic specific, the consideration as a biomarker should be tailored to specific population group. To substantiate this, studies from the Asian regions, using more reliable genotyping technique are recommended.

\section{Abbreviations}

$\mathrm{Cl}$ - Confidence interval

EBV - Epstein-Barr virus

GC - Gastric cancer

GEPIA- Gene expression profiling and interactive analyses

H. pylori- Helicobacter pylori

HWE - Hardy-Weinberg Equilibrium

NOS - Newcastle-Ottawa Scale

OR - Odds ratio

RevMan- Review Manager

SNP - Single nucleotide polymorphism

TNF - Tumour necrotic factor

TSA - Trial sequential analysis 


\section{Declarations}

\section{Ethics approval (and consent to participate)}

The need for approval was waived as this study solely used published human data.

\section{Consent for publication}

Not applicable.

\section{Availability of data and materials}

All data generated or analyzed during this study are included in this article and its supplementary information files.

\section{Competing interests}

The authors declare that they have no competing interests.

\section{Funding}

This work was supported by a grant from the Fundamental Research GrantScheme (FRGS) of Malaysian Ministry of Education (FRGS/1/2018/SKK03/IMU/02/1 for this research team). The content is solely the responsibility of the authors and does not necessarily represent the funding agency. The funding agency did not have a role in the design of the study, the collection, analysis, and interpretation of data, or the writing of the manuscript.

\section{Authors' contributions}

JWM Conceptualized; JWM, KS, WST, NHH, CN, TTW participated in the design; WST, NHH, CN, TTW data acquisition; CN, NHH, WST performed data analysis, data interpretation. CN drafted the manuscript; JWM, WST, NHH substantively contributed during the writing progress. All authors read and approved the final manuscript

\section{Acknowledgements}

The authors gratefully acknowledge the participants and researchers of the primary studies. We thank our institutions for allowing us to perform this study.

\section{References}

1. Ferlay J, Colombet M, Soerjomataram I, Mathers C, Parkin DM, Piñeros M. Estimating the global cancer incidence and mortality in 2018 : GLOBOCAN sources and methods. Int J Cancer.2019;144(8):1941-53.

2. El-Omar EM, Rabkin CS, Gammon MD, Vaughan TL, Risch HA, Schoenberg JB, et al. Increased risk of noncardia gastric cancer associated with proinflammatory cytokine gene polymorphisms. Gastroenterology.2003;124:1193-201.

3. Kelley JR, Duggan JM. Gastric cancer epidemiology and risk factors. J Clin Epidemiol. 2003;56(1):1-9.

4. Ferlay J, Steliarova-Foucher E, Lortet-Tieulent J, Rosso S, Coebergh JW, Comber H. Cancer incidence and mortality patterns in Europe: estimates for 40 countries in 2012. Eur J Cancer. 2013;49(6):1374-403.

5. Hong Y, Ge Z, Changrui Jing C, Shi J, Dong X, Zhou F, et al. Functional promoter -308G>A variant in tumor necrosis factor a gene is associated with risk and progression of gastric cancer in a Chinese population. PLoS One.2013;8(1):e50856.

6. Peleteiro B, Bastos A, Ferro A, Lunet N. Prevalence of Helicobacter pylori infection worldwide: a systematic review of studies with national coverage. Dig Dis Sci. 2014;59(8):1698-709.

7. Tan P, Yeoh KG. Genetics and Molecular Pathogenesis of Gastric Adenocarcinoma. Gastroenterology.2015;149(5):1153-62.

8. Waters JP, Pober JS, Bradley JR. Tumour necrosis factor and cancer. J Pathol.2013; 230: 241-8.

9. Coussens LM, Werb Z. Inflammation and cancer. Nature.2002;420(6917):860-7. 
10. Machado JC, Figueiredo C, Canedo P, Pharoah P, Carvalho R, Nabais S, et al. A proinflammatory genetic profile increases the risk for chronic atrophic gastritis and gastric carcinoma. Gastroenterology.2003;125:364-71.

11. Du LC, Gao R. Role of TNF-a -308G/A gene polymorphism in gastric cancer risk: A case control study and meta-analysis. Turk J Gastroenterol. 2017;28(4):272-82

12. Jang WH, Yang YI, Yea SS, Lee YJ, Chun JH, Kim HI, et al. The -238 tumor necrosis factor-alpha promoter polymorphism is associated with decreased susceptibility to cancers. Cancer Lett.2001;166:41-6.

13. Glas J, Torok HP, Schneider A, Brunnler G, Kopp R, Albert ED, et al. Allele 2 of the interleukin-1 receptor antagonist gene is associated with early gastric cancer. J Clin Oncol.2004;22:4746-52.

14. Whiteman DC, Parmar P, Fahey P, Moore SP, Stark M, Zhao ZZ. Association of Helicobacter pylori infection with reduced risk for esophageal cancer is independent of environmental and genetic modifiers. Gastroenterology.2010;139:73-83.

15. Naing C, Htet NH, Siew Tung W, Basavaraj AK, Mak JW (2018) Association of tumournecrosis factor-a(TNF-a) gene polymorphisms (-308 $\mathrm{G}>$ Aand -238 G>A)and the risk of severe dengue: A meta-analysis and trial sequential analysis. PLoS ONE 13(10):e0205413

16. Wells BS GA, O'Connell D, Peterson J, Welch V, Losos MP. The Newcastle-Ottawa Scale (NOS) for assessing the quality of nonrandomised studies in meta-analyses 2014. http://www.ohri.ca/programs/ clinical_epidemiology/oxford.asp

17. Guo SW, Thompson EA. Performing the exact test of Hardy-Weinberg proportion for multiple alleles. Biometrics.1992;48(2):361-72.

18. Thakkinstian A, McElduff P, D'Este C, Duffy D, Attia J. A method for meta-analysis of molecular association studies. Statistics in Medicine. 2005;24(9): 1291-306.

19. Higgins JP, Thompson SG, Deeks JJ, Altman DG. Measuring inconsistency in meta-analyses. BMJ.2003.327: 557-60.

20. Egger M, Smith GD, Schneider M, Minder C. Bias in meta-analysis detected by a simple, graphical test. BMJ. 1997;315(7109):629-34.

21. Sterne JA, Egger M. Funnel plots for detecting bias in meta-analysis: guidelines on choice of axis. J Clin Epidemiol 2001;54(10):1046-55.

22. Thorlund K, Walter SD, Johnston BC, Furukawa TA, Guyatt, GH. Pooling health-related quality of life outcomes in meta-analysis-a tutorial and review of methods for enhancing interpretability Res Syn Meth. 2011;2:188-203.

23. Brok J, Thorlund K, Wetterslev J, Gluud C. Apparently conclusive meta-analyses may be inconclusive--Trial sequential analysis adjustment of random error risk due to repetitive testing of accumulating data in apparently conclusive neonatal meta-analyses. Int $J$ Epidemiol. 2009;38(1):287-98.

24. Wu MS, Huang SP, Chang YT, Shun CT, Chang MC, Lin MT, et al. Tumor necrosis factor-alpha and interleukin-10 promoter polymorphisms in Epstein-Barr virus-associated gastric carcinoma.J Infect Dis. 2002;185:106-9.

25. Fei BY, Xia B, Deng CS, Xia XQ, Xie M, Crusius JBA, et al. Association of tumor necrosis factor genetic polymorphism with chronic atrophic gastritis and gastric adenocarcinoma in Chinese Han population. World J Gastroenterol.2004;10:1256-61.

26. Lee SG, Kim B, Yook JH, Oh ST, Lee I, Song K. TNF/LTA polymorphisms and risk for gastric cancer/duodenal ulcer in the Korean population. Cytokine.2004;28:75-82.

27. Wu MS, Chen LT, Shun CT, Huang SP, Chiu HM, Wang HP, Lin MT, Cheng AL, Lin JT. Promoter polymorphisms of tumor necrosis factoralpha are associated with risk of gastric mucosa-associated lymphoid tissue lymphoma. Int J Cancer. 2004;110:695-700.

28. Garza-Gonzalez E, Bosques-Padilla FJ, El Omar E, Hold G, Tijerina-Menchaca R, Maldonado-Garza HJ, et al. Role of the polymorphic IL-1B, IL-1RN and TNF-A genes in distal gastric cancer in Mexico. Int J Cancer.2005;114:237-41.

29. Lee JY, Kim HY, Kim KH, Kim SM, Jang MK, Park JY, et al. Association of polymorphism of IL-10 and TNF-A genes with gastric cancer in Korea. Cancer Lett.2005;225:207-14

30. Li C, Xia B, Yang Y, Li J, Xia HH. TNF gene polymorphisms and Helicobacter pylori infection in gastric carcinogenesis in Chinese population. Am J Gastroenterol.2005; 100:290-4. 
31. Lu W, Pan K, Zhang L, Lin D, Miao X, You W. Genetic polymorphisms of interleukin (IL)-1B, IL-1RN, IL-8, IL-10 and tumor necrosis factor \{alpha\} and risk of gastric cancer in a Chinese population. Carcinogenesis.2005;26:631-6.

32. Perri F, Piepoli A, Bonvicini C, Gentile A, Quitadamo M, Di Candia M, et al. Cytokine gene polymorphisms in gastric cancer patients from two Italian areas at high and low cancer prevalence. Cytokine.2005;30(5):293-302.

33. Rocha GA, Guerra JB, Rocha AM, Saraiva IE, da Silva DA, de Oliveira CA, et al. IL 1RN polymorphic gene and Cag A-positive status independently increase the risk of non-cardia gastric carcinoma. Int J Cancer.2005;115:678-83.

34. Zambon CF, Basso D, Navaglia F, Belluco C, Falda A, Fogar P, et al. Pro- and anti-inflammatory cytokines gene polymorphisms and Helicobacter pylori infection: Interactions influence outcome. Cytokine. 2005;29:141-52.

35. Kamangar F, Abnet CC, Hutchinson AA, Newschaffer CJ, Helzlsouer K, Shugart YY, et al. Polymorphisms in inflammation-related genes and risk of gastric cancer (Finland) Cancer Causes Control.2006;17:117-25.

36. Kim N, Cho SI, Yim JY, Kim JM, Lee DH, Park JH, et al. (2006) The effects of genetic polymorphisms of IL-1 and TNF-A on Helicobacter pylori-induced gastroduodenal diseases in Korea. Helicobacter.2006;11:105-12.

37. Morgan DR, Dominguez RL, Keku TO, Heidt PE, Martin CF, Galanko JA, et al Gastric cancer and the high combination prevalence of host cytokine genotypes and Helicobacter pylori in Honduras. Clin Gastroenterol Hepatol. 2006;4:1103-11.

38. Garcia-Gonzalez MA, Lanas A, Quintero E, Nicolas D, Parra-Blanco A, Strunk M, et al. Gastric cancer susceptibility is not linked to pro- and anti-inflammatory cytokine gene polymorphisms in whites: a nationwide multicenter study in Spain. Am J Gastroenterol.2007;102:1878-92.

39. Hou L, El-Omar EM, Chen J, Grillo P, Rabkin CS, Baccarelli A, et al. Polymorphisms in Th1-type cell-mediated response genes and risk of gastric cancer. Carcinogenesis.2007; 28:118-23.

40. Sugimoto M, Furuta T, Shirai N, Nakamura A, Xiao F, Kajimura M, Sugimura H, Hishida A. Different effects of polymorphisms of tumor necrosis factor-alpha and interleukin-1 beta on development of peptic ulcer and gastric cancer. J Gastroenterol Hepatol. 2007;22:51-9.

41. Canedo P, Duraes C, Pereira F, Regalo G, Lunet N, Barros H, et al. Tumor necrosis factor alpha extended haplotypes and risk of gastric carcinoma. Cancer Epidemiol Biomarkers Prev. 2008;17:2416-20.

42. Crusius JB, Canzian F, Capella G, Peña AS, Pera G, Sala N, et al. Cytokine gene polymorphisms and the risk of adenocarcinoma of the stomach in the European prospective investigation into cancer and nutrition (EPIC-EURGAST). Ann Oncol.2008;19:1894-902.

43. Melo Barbosa HP, Martins LC, dos Santos SE, Demachki S, Assumpção MB, et al. Interleukin-1 and TNF-a polymorphisms and Helicobacter pylori in a Brazilian Amazon population. World J Gastroenterol 2009; 15(12): 1465-71.

44. Yang JJ, Ko KP, Cho LY, Shin A, Gwack J, Chang SH, et al. The role of TNF genetic variants and the interaction with cigarette smoking for gastric cancer risk: a nested case-control study. BMC Cancer.2009;9:238.

45. Burada F, Angelescu C, Mitrut P, Ciurea T, Cruce M, Saftoiu A, et al. Interleukin-4 receptor -3223T\& amp; \#8594; C polymorphism is associated with increased gastric adenocarcinoma risk. Can J Gastroenterol.2012;26:532-6.

46. Santos JC, Ladeira MS, Pedrazzoli J, Jr, Ribeiro ML. Relationship of IL-1 and TNF-a polymorphisms with Helicobacter pylori in gastric diseases in a Brazilian population. Braz J Med Biol Res. 2012;45:811-7.

47. Oliveira JG, Duarte MC, Silva AE. IL-1ra anti-inflammatory cytokine polymorphism is associated with risk of gastric cancer and chronic gastritis in a Brazilian population, but the TNF- $\beta$ pro-inflammatory cytokine is not. Mol Biol Rep. 2012;39:7617-25

48. Bhayal AC, Krishnaveni D, RangaRao KP, Bogadi V, Suman C, Jyothy A, et al. Role of tumor necrosis factor-a -308 G/A promoter polymorphism in gastric cancer Saudi J Gastroenterol.2013;19(4):182-6.

49. Zabaglia LM, Ferraz MA, Pereira WN, Orcini WA, de Labio RW, Neto AC et al. Lack of association among TNF-a gene expression, -308 polymorphism (G>A) and virulence markers of Helicobacter pylori. J Venom Anim Toxins Incl Trop Dis 2015; 21 : 54

50. Gorouhi F, Islami F, Bahrami H, Kamangar F. Tumour-necrosis factor-A polymorphisms and gastric cancer risk: a meta-analysis. Br J Cancer. 2008;98:1443-51

Page 9/19 
51. Yang JP, Hyun MH, Yoon JM, Park MJ, Kim D, Park S. Association between TNF-a-308 G/A gene polymorphism and gastric cancer risk: a systematic review and meta-analysis. Cytokine 2014; 70: 104-14.

52. Zhao L, Zhang F, Ding X, Wu G, Lam YY, Wang X, et al. Gut bacteria selectively promoted by dietary fibers alleviate type 2 diabetes. Science. $2018 ; 359(6380): 1151-6$.

53. Genta RM. The immunobiology of Helicobacter pylori gastritis. Semin Gastrointest Dis. 1997;8(1):2-11.

54. Beales IL, Calam J. Interleukin 1 beta and tumour necrosis factor alpha inhibit acid secretion in cultured rabbit parietal cells by multiple pathways. Gut.1998;42:227-234.

55. Sanduleanu S, Jonkers D, De Bruine A, Hameeteman W, Stockbrugger RW. Double gastric infection with Helicobacter pylori and nonHelicobacter pylori bacteria during acid-suppressive therapy: increase of pro-inflammatory cytokines and development of atrophic gastritis. Aliment Pharmacol Ther 2001;15: 1163-75.

56. Sunakawa Y, Lenz HJ. Molecular classification of gastric adenocarcinoma: translating new insights from the cancer genome atlas research network. Curr Treat Options Oncol. 2015;16(4):17.

57. Shen GQ, Abdullah KG, Wang QK. The TaqMan method for SNP genotyping. Methods Mol Biol. 2009;578:293-306.

58. Zheng W, Zhang S, Zhang S, Min L, Wang Y, Xie J, et al. The relationship between tumor necrosis factor-a polymorphisms and gastric cancer risk: An updated meta-analysis. Biomed Rep.2017;7(2): 33-42.

59. Guo XF, Wang J, Yu SJ, Guo XF, Wang J, Yu SJ, et al. TNF-a-308 polymorphism and risk of digestive system cancers: a meta-analysis. World J Gastroenterol. 2013; 19: 9461-71.

60. Zhu F, Zhao H, Tian X, Meng X. Association between tumor necro-sis factor-a rs1800629 polymorphism and risk of gastric cancer: a meta-analysis. Tumour Biol 2014; 35: 1799-803

\section{Tables}

Table 1 Characteristics of the studies included in the meta-analysis 


\begin{tabular}{|c|c|c|c|c|c|c|c|c|c|c|c|c|c|c|}
\hline & $\begin{array}{l}\text { Author, } \\
\text { year }\end{array}$ & $\begin{array}{l}\text { Ref } \\
\text { no. }\end{array}$ & Country & Ethnicity & $\begin{array}{l}\text { Cases/ } \\
\text { Controls }\end{array}$ & $\begin{array}{l}\text { Age } \\
\text { group }\end{array}$ & Males & $\begin{array}{l}\text { Type } \\
\text { of } \\
\text { cancer }\end{array}$ & Smokers & $\begin{array}{l}\text { Study } \\
\text { design }\end{array}$ & $\begin{array}{l}\text { Genotyping } \\
\text { method }\end{array}$ & $\begin{array}{l}\text { HP } \\
\text { +ve }\end{array}$ & $\begin{array}{l}\text { HWE, } \\
p \\
\text { value }\end{array}$ & $\begin{array}{l}\text { NOS } \\
\text { criteria }\end{array}$ \\
\hline 1 & Jang, 2001 & 12 & $\begin{array}{l}\text { South } \\
\text { Korea }\end{array}$ & Asian & $52 / 92$ & adult & NA & GAC & NA & $\mathrm{CC}$ & $\begin{array}{l}\text { Nested } \\
\text { PCR }\end{array}$ & NA & 0.704 & 5 \\
\hline 2 & Wu, 2002 & 24 & Taiwan & Asian & $\begin{array}{l}\text { 120/220 } \\
\text { (others: } \\
\text { EBV) }\end{array}$ & adult & NA & GC & NA & CC & $\begin{array}{l}\text { PCR, } \\
\text { dir seq }\end{array}$ & NA & 0.000 & 5 \\
\hline 3 & $\begin{array}{l}\text { El-Omar, } \\
2003\end{array}$ & 2 & USA & Caucasian & $314 / 210$ & adult & $\begin{array}{r}87 \% \\
77 \% \\
\end{array}$ & $\begin{array}{l}\text { GC-C } \\
\text { GC- } \\
\text { NC }\end{array}$ & $\begin{array}{l}\text { Yes } \\
(80 \%)\end{array}$ & $\mathrm{CC}$ & TaqMan & $46 \%$ & 0.548 & 8 \\
\hline 4 & $\begin{array}{l}\text { Machado, } \\
2003\end{array}$ & 10 & Portugal & Caucasian & $287 / 306$ & adult & $58.3 \%$ & GC & NA & $\mathrm{CC}$ & PCR & $61.3 \%$ & 0.649 & 5 \\
\hline 5 & Fei, 2004 & 25 & China & Asian & $56 / 164$ & & $76.8 \%$ & GAC & NA & $\mathrm{CC}$ & PCR & NA & 0.743 & 4 \\
\hline 6 & Glas, 2004 & 13 & Germany & Caucasian & $88 / 145$ & adult & $46.6 \%$ & GC & NA & $\mathrm{CC}$ & PCR & $88 \%$ & 0.669 & 5 \\
\hline 7 & Lee, 2004 & 26 & $\begin{array}{l}\text { South } \\
\text { Korea }\end{array}$ & Asian & $341 / 261$ & adult & $58.4 \%$ & GC & NA & $\mathrm{CC}$ & PCR & NA & 0.493 & 7 \\
\hline 8 & Wu, 2004 & 27 & Taiwan & Asian & $204 / 210$ & adult & $61.8 \%$ & GAC & NA & $\mathrm{CC}$ & $\begin{array}{l}\text { PCR, dir } \\
\text { seq }\end{array}$ & $80.4 \%$ & 0.000 & 5 \\
\hline 9 & $\begin{array}{l}\text { Garcıa- } \\
\text { Gonzalez, } \\
2005\end{array}$ & 28 & Spain & Caucasian & $63 / 215$ & adult & $64.1 \%$ & GC & NA & $\mathrm{CC}$ & PCR & $49.2 \%$ & 0.607 & 5 \\
\hline 10 & Lee, 2005 & 29 & $\begin{array}{l}\text { South } \\
\text { Korea }\end{array}$ & Asian & $122 / 120$ & adult & $59 \%$ & GC & NA & CC & PCR & $81 \%$ & 0.403 & 5 \\
\hline 11 & Li, 2005 & 30 & China & Asian & $59 / 264$ & adult & $66.1 \%$ & $\begin{array}{l}\text { GC- } \\
\text { NC }\end{array}$ & NA & $\mathrm{CC}$ & PCR-RFLP & $93.2 \%$ & 0.559 & 5 \\
\hline 12 & Lu, 2005 & 31 & China & Asian & $250 / 300$ & adult & $73.2 \%$ & GC & $\begin{array}{l}\text { Yes } \\
(57.2 \%)\end{array}$ & CC & PCR & $70.4 \%$ & 0.559 & 8 \\
\hline 13 & $\begin{array}{l}\text { Perri, } \\
2005\end{array}$ & 32 & Italy & Caucasian & $184 / 366$ & adult & $59.8 \%$ & GAC & NA & $\mathrm{CC}$ & PCR & 77.1 & 0.145 & 4 \\
\hline 14 & $\begin{array}{l}\text { Rocha, } \\
2005\end{array}$ & 33 & Brazil & Caucasian & $166 / 536$ & adult & $69.9 \%$ & $\begin{array}{l}\mathrm{GC}- \\
\mathrm{NC}\end{array}$ & NA & CC & PCR-RFLP & $100 \%$ & 0.345 & 7 \\
\hline 15 & Zambo, & 34 & Italy & Caucasian & $129 / 792$ & adult & $60.5 \%$ & $\mathrm{NC}$ & NA & CC & Taqman & $84 \%$ & 0.909 & 4 \\
\hline
\end{tabular}




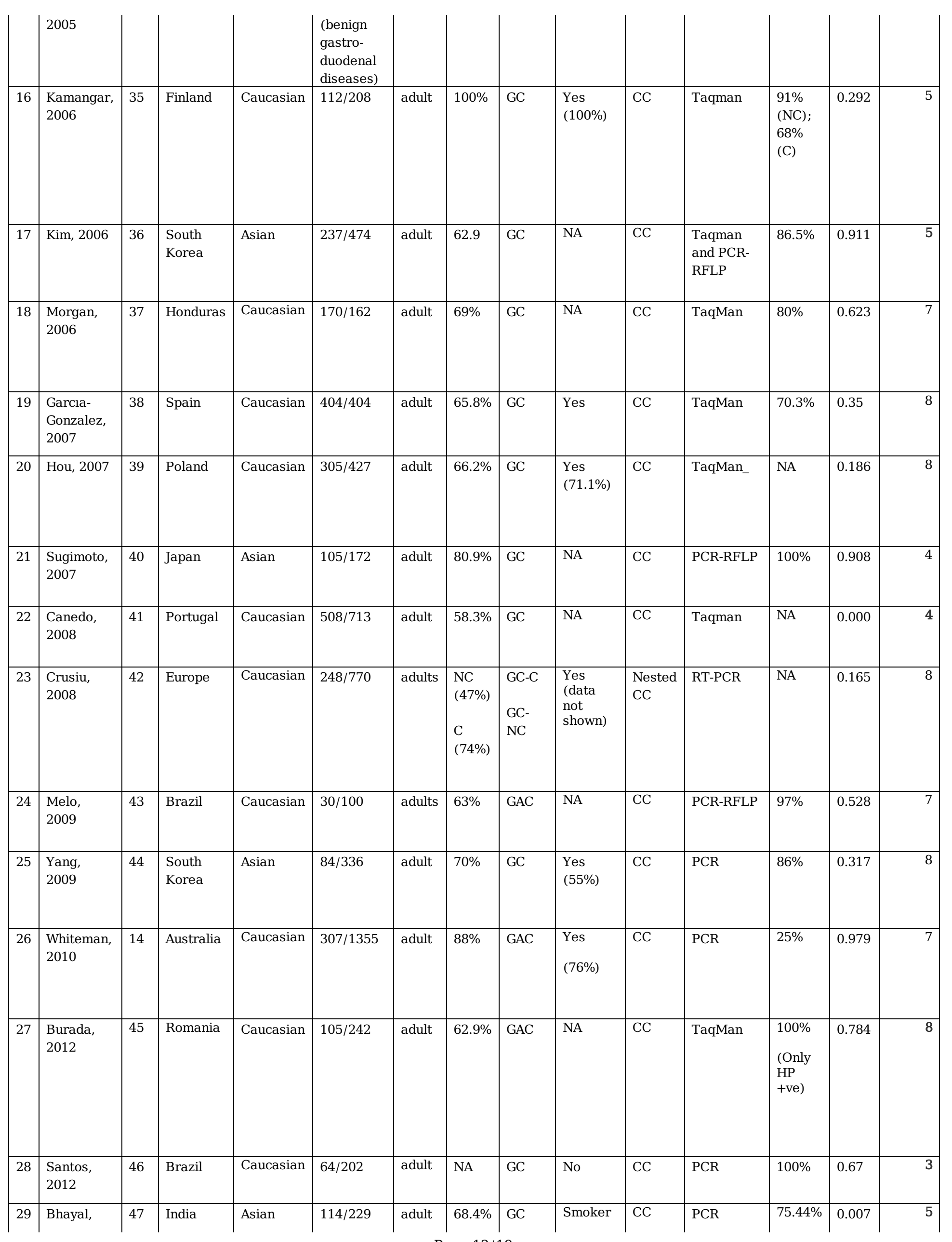




\begin{tabular}{|c|c|c|c|c|c|c|c|c|c|c|c|c|c|c|}
\hline & 2013 & & & & & & & & (42.1\%) & & & & & \\
\hline 30 & $\begin{array}{l}\text { Hong, } \\
2013\end{array}$ & 5 & China & Asian & $1686 / 1894$ & adult & $73 \%$ & $\begin{array}{l}\text { GC-C } \\
\text { GC- } \\
\text { NC }\end{array}$ & NA & $\mathrm{CC}$ & TaqMan & NA & 0.376 & 8 \\
\hline 31 & $\begin{array}{l}\text { Oliveira, } \\
2015\end{array}$ & 48 & Brazil & Caucasian & $207 / 240$ & adult & $77.8 \%$ & GC & $\begin{array}{l}\text { Yes } \\
\text { (data } \\
\text { not } \\
\text { shown) }\end{array}$ & $\mathrm{CC}$ & $\begin{array}{l}\text { SYBR } \\
\text { Green\& } \\
\text { Taqman }\end{array}$ & NA & 0.296 & 5 \\
\hline 32 & $\begin{array}{l}\text { Zabaglia, } \\
2015\end{array}$ & 49 & Brazil & Caucasian & $24 / 40$ & adult & $45.5 \%$ & GC & NA & $\mathrm{CC}$ & Taqman & $87.5 \%$ & 0.000 & 3 \\
\hline 33 & $\mathrm{Du}, 2017$ & 11 & China & Asian & $400 / 400$ & adult & $70 \%$ & GC & $\begin{array}{l}\text { Yes } \\
\text { (data } \\
\text { not } \\
\text { shown) }\end{array}$ & $\begin{array}{l}\text { CC, } \\
\text { MA }\end{array}$ & $\begin{array}{l}\text { allele- } \\
\text { specific } \\
\text { PCR }\end{array}$ & NA & 0.000 & 7 \\
\hline
\end{tabular}

Ref no.: Reference number; CC: case-control design; dir seq: direct sequencing HP +ve: $H$. pylori positive; GAC: gastric adenocarcinoma; GC: gastric cancer in general, not specified; NC: non-cardia cancer; C: cardia; MA: meta- analysis; HWE: Hardy-Weinberg Equilibrium; NOS criteria: 0-9 score; RTPCR: Real-time PCR; NA: not available/not reported/not shown

Table 2: Distribution of gene frequencies in the studies 


\begin{tabular}{|c|c|c|c|c|c|c|c|c|}
\hline \multirow[t]{2}{*}{ Study } & \multirow[t]{2}{*}{ Year } & \multirow[t]{2}{*}{ Ref. No. } & \multicolumn{3}{|c|}{ Cases } & \multicolumn{3}{|c|}{ Controls } \\
\hline & & & $\mathrm{G} / \mathrm{G}$ & $\mathrm{G} / \mathrm{A}$ & $\mathrm{A} / \mathrm{A}$ & $\mathrm{G} / \mathrm{G}$ & $\mathrm{G} / \mathrm{A}$ & $\mathrm{A} / \mathrm{A}$ \\
\hline Jang & 2001 & 12 & 46 & 4 & 2 & 85 & 7 & 0 \\
\hline $\mathrm{Wu}$ & 2002 & 24 & 96 & 17 & 7 & 180 & 27 & 13 \\
\hline El-Omar & 2003 & 2 & 201 & 87 & 26 & 152 & 52 & 6 \\
\hline Machado & 2003 & 10 & 179 & 105 & 3 & 231 & 69 & 4 \\
\hline Fei & 2004 & 25 & 53 & 3 & 0 & 143 & 20 & 1 \\
\hline Glas & 2004 & 13 & 66 & 19 & 3 & 105 & 36 & 4 \\
\hline Lee & 2004 & 26 & 218 & 43 & 1 & 297 & 42 & 1 \\
\hline $\mathrm{Wu}$ & 2004 & 27 & 163 & 29 & 12 & 171 & 26 & 13 \\
\hline Garcıa-Gonzalez & 2005 & 28 & 0 & 8 & 55 & 1 & 35 & 179 \\
\hline Lee & 2005 & 29 & 112 & 10 & 0 & 103 & 17 & 0 \\
\hline $\mathrm{Li}$ & 2005 & 30 & 55 & 4 & 0 & 228 & 34 & 2 \\
\hline $\mathrm{Lu}$ & 2005 & 31 & 214 & 36 & 0 & 274 & 24 & 2 \\
\hline Perri & 2005 & 32 & 71 & 14 & 1 & 118 & 24 & 4 \\
\hline Rocha & 2005 & 33 & 120 & 37 & 4 & 399 & 123 & 13 \\
\hline Zambo & 2005 & 34 & 95 & 31 & 3 & 496 & 138 & 10 \\
\hline Kamangar & 2006 & 35 & 86 & 23 & 3 & 154 & 52 & 2 \\
\hline Kim & 2006 & 36 & 199 & 34 & 4 & 400 & 59 & 2 \\
\hline Morgan & 2006 & 37 & 151 & 17 & 0 & 149 & 12 & 0 \\
\hline Garcı-Gonzalez & 2007 & 38 & 309 & 84 & 11 & 320 & 77 & 7 \\
\hline Hou & 2007 & 39 & 186 & 98 & 21 & 304 & 109 & 15 \\
\hline Sugimoto & 2007 & 40 & 101 & 4 & 0 & 169 & 3 & 0 \\
\hline Canedo & 2008 & 41 & 330 & 178 & 0 & 544 & 169 & 0 \\
\hline Crusiu & 2008 & 42 & 170 & 64 & 2 & 820 & 274 & 31 \\
\hline Melo & 2009 & 43 & 24 & 5 & 1 & 86 & 13 & 1 \\
\hline Yang & 2009 & 44 & 75 & 8 & 0 & 288 & 34 & 0 \\
\hline
\end{tabular}

Page 14/19 


\begin{tabular}{|c|c|c|c|c|c|c|c|c|}
\hline Whiteman & 2010 & 14 & 196 & 93 & 6 & 842 & 403 & 48 \\
\hline Burada & 2010 & 45 & 78 & 26 & 1 & 196 & 44 & 2 \\
\hline Santos & 2012 & 46 & 44 & 20 & 0 & 22 & 4 & 0 \\
\hline Bhayal & 2013 & 47 & 32 & 76 & 6 & 76 & 128 & 25 \\
\hline Hong & 2013 & 5 & 1335 & 333 & 18 & 1585 & 295 & 14 \\
\hline Oliveira & 2015 & 48 & 138 & 66 & 3 & 167 & 69 & 4 \\
\hline Zabaglia & 2015 & 49 & 17 & 4 & 3 & 33 & 4 & 3 \\
\hline $\mathrm{Du}$ & 2017 & 11 & 204 & 184 & 12 & 326 & 60 & 14 \\
\hline
\end{tabular}

Table 3. Sensitivity analysis of studies with Hardy-Weinberg Equilibrium

\begin{tabular}{|c|c|c|c|}
\hline Description & Number of studies included & $\begin{array}{l}\text { Overall risk } \\
\text { OR ( } 95 \% \mathrm{CI})\end{array}$ & Subgroup analysis \\
\hline dominant model & $\begin{array}{c}27 \\
\text { Asians (10), } \\
\text { Caucasians (17) }\end{array}$ & $\begin{array}{c}1.2(1.1-1.3) ; \\
I^{2}: 37 \%\end{array}$ & $\begin{array}{c}\text { Asians, } \\
1.20[1.05,1.38] \\
\text { Caucasians: } \\
1.20[1.08,1.32]\end{array}$ \\
\hline recessive model & Do & $\begin{array}{c}1.27(1.0-1.62) ; \\
I^{2}: 0 \%\end{array}$ & $\begin{array}{c}\text { Asians, } \\
1.50[0.88,2.55] \\
\text { Caucasians: } \\
1.22[0.93,1.60]\end{array}$ \\
\hline additive model & Do & $1.31(1.08-1.32) ; I^{2: 0 \%}$ & $\begin{array}{c}\text { Asians, } \\
1.53[0.91,2.56] \\
\\
\text { Caucasians: } \\
1.25[0.94,1.67]\end{array}$ \\
\hline allelic contrast model & Do & 1.17 (0.98-1.39); $I^{2}: 75 \%$. & $\begin{array}{c}\text { Asians: } \\
1.06[0.81,1.39] \\
\text { Caucasians: } \\
1.24[0.97,1.58]\end{array}$ \\
\hline
\end{tabular}

Significant association is indicated in bold. 


\section{Figures}

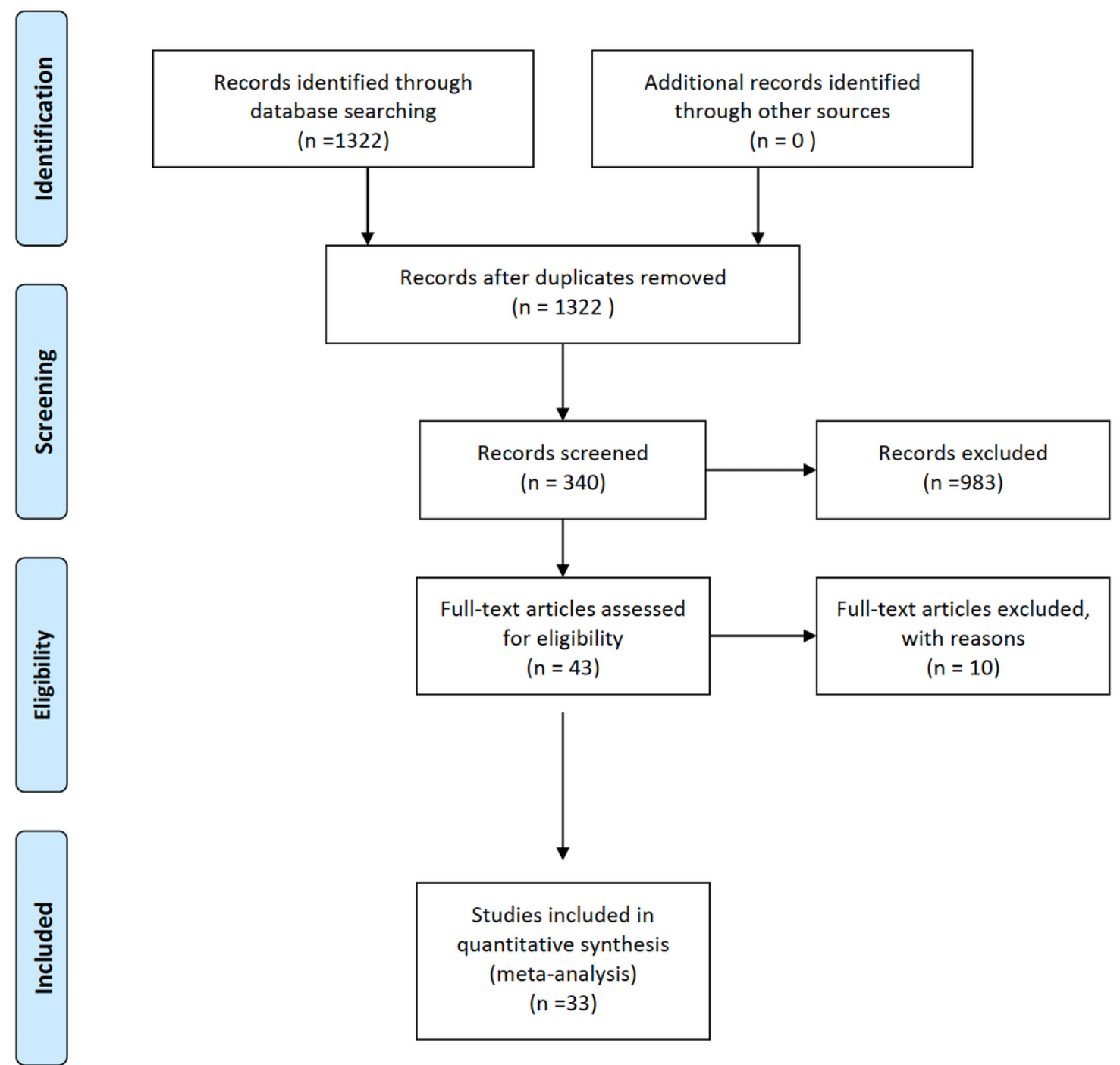

\section{Figure 1}

Study selection process 


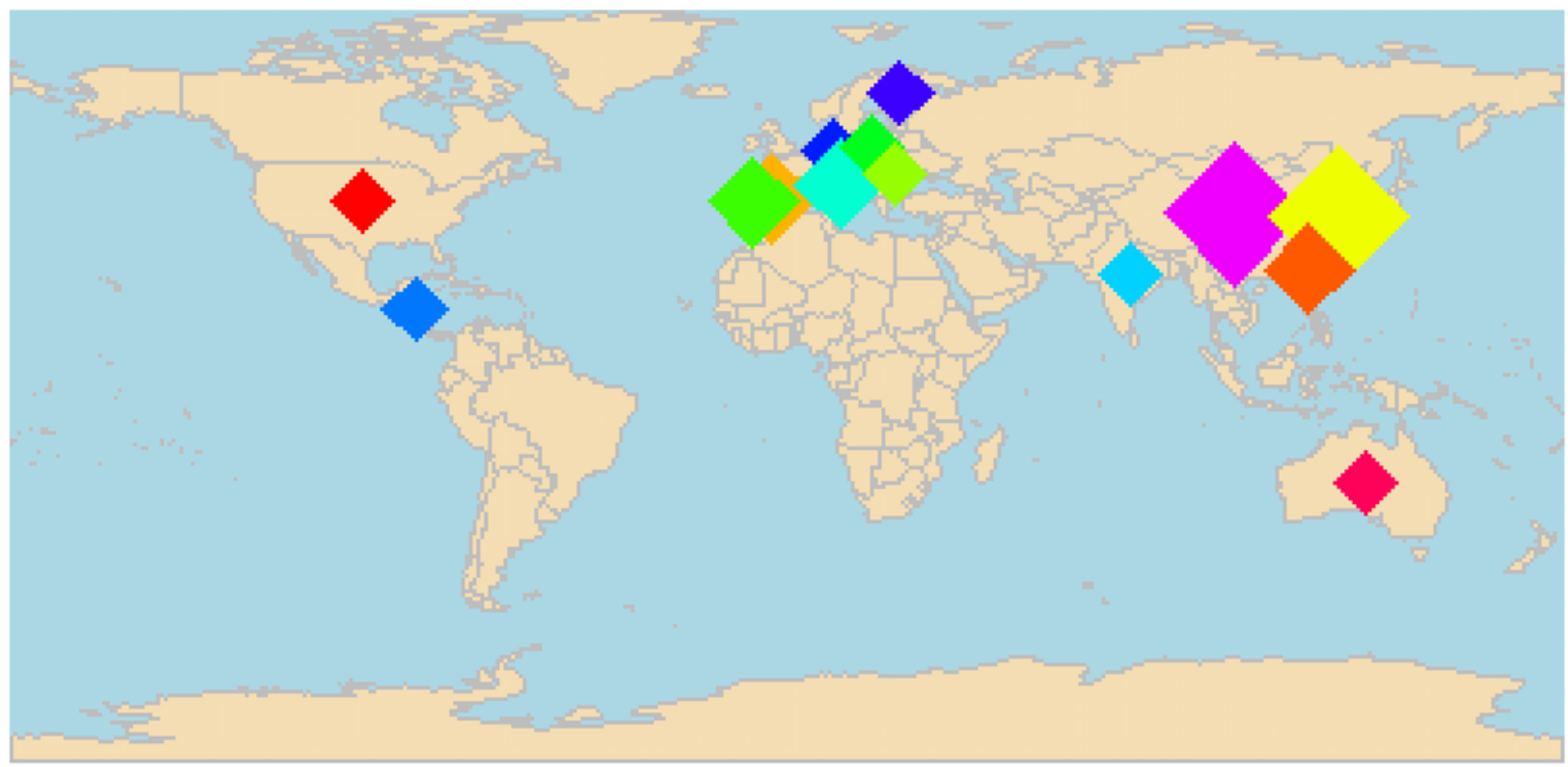

\section{Figure 2}

Geographical distribution of included studies 


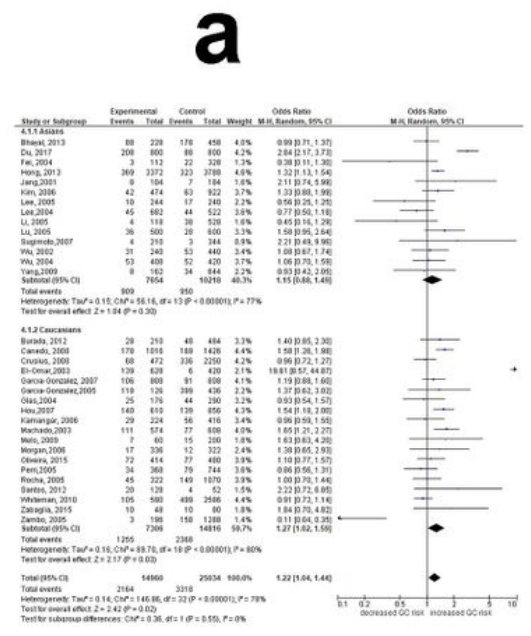

b

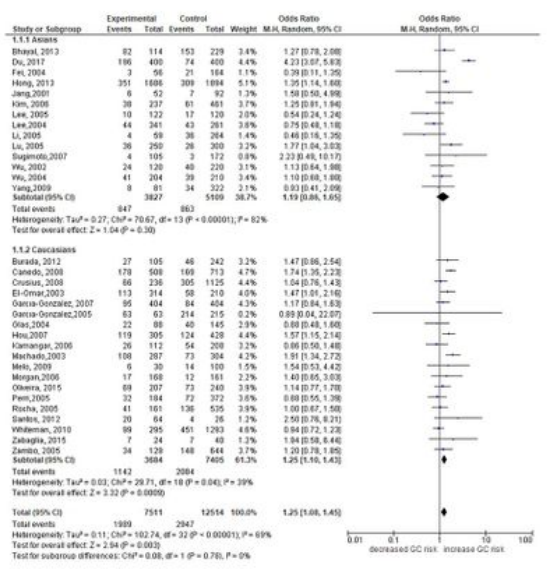

C
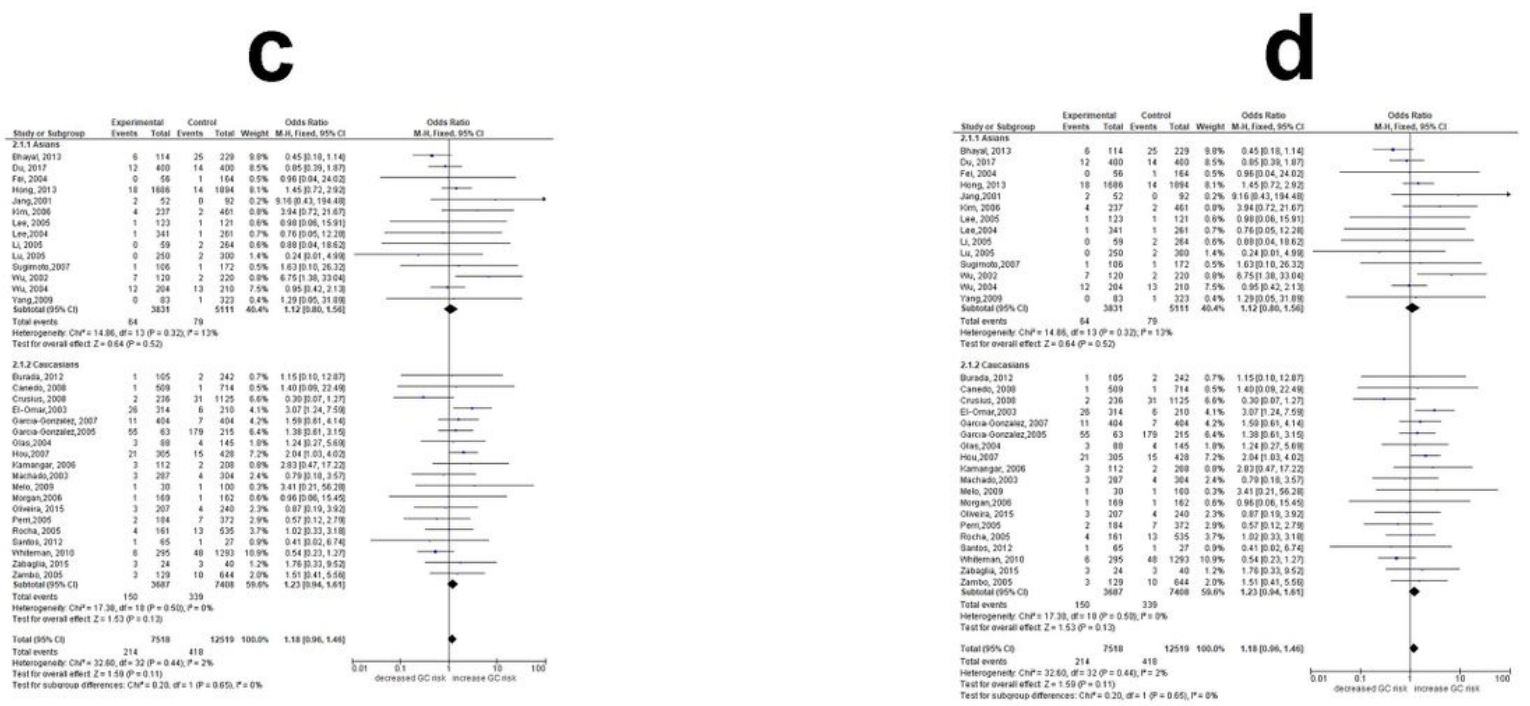

\section{Figure 3}

Forest plot of gastric cancer risk associated with TNF-a 308 G/A polymorphism by ethnic group 3A: Allelic model 3B: Dominant model 3C: Additive model 3D: Recessive model 


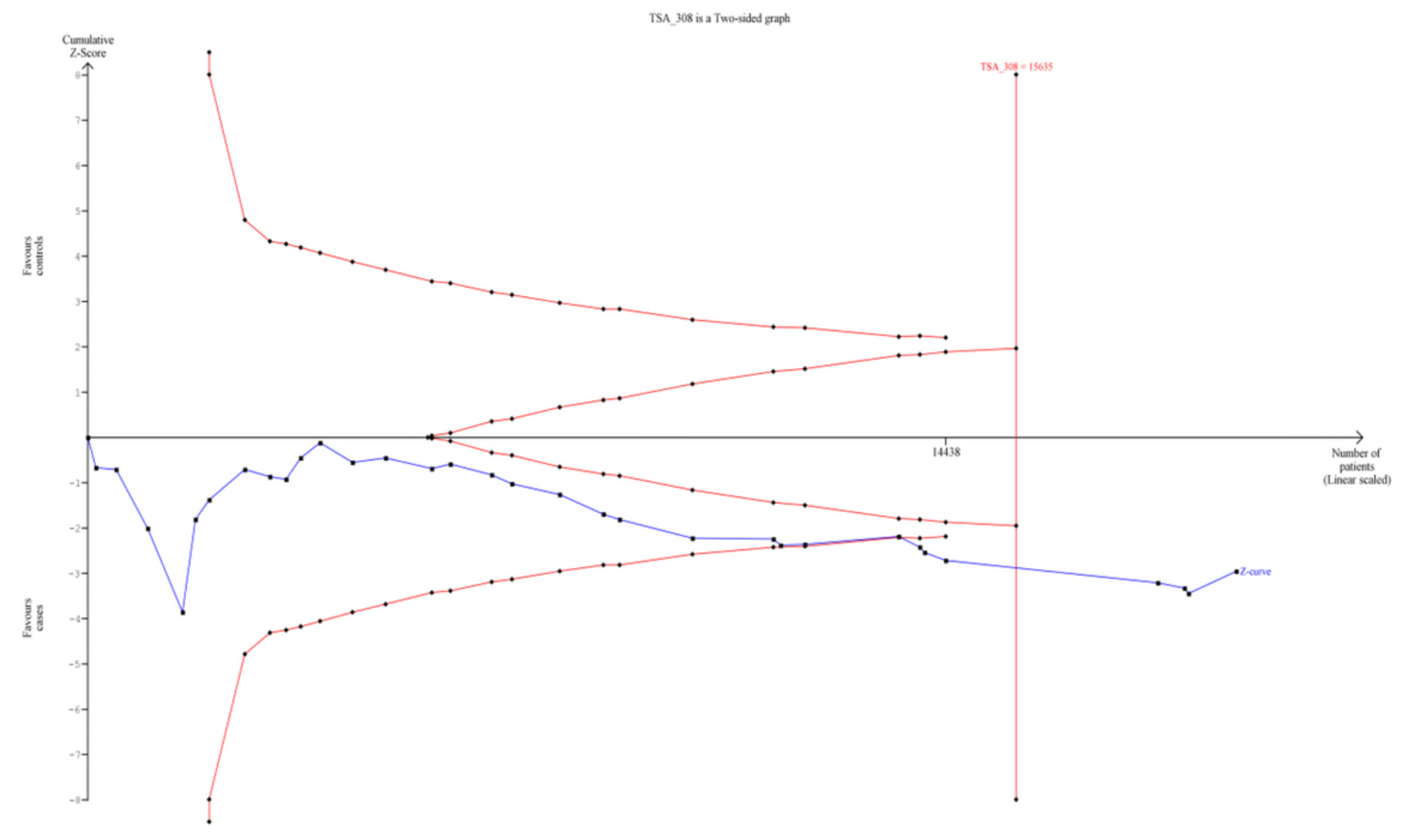

Figure 4

Trial sequential monitoring plot of TNF-囚-308 in gastric cancer risk under dominant model

\section{Supplementary Files}

This is a list of supplementary files associated with this preprint. Click to download.

- FigS1quality.pdf

- FigureS4Funnelplot.pdf

- FigureS2.pdf

- Tables1.doc

- FigS3.pdf 